\title{
ПАРАДИГМА ЕФЕКТИВНОГО ФУНКЦІОНУВАННЯ ІНВЕСТИЦЙНОГО ПРОЦЕСУ СОЦІАЛЬНО-ЕКОНОМІЧНОГО РОЗВИТКУ РЕГІОНУ
}

\author{
DOI: 10.32620/cher.2019.3.10
}

\begin{abstract}
Постановка проблеми. Активізація інвестиційної діяльності та значне нарощування обсягів інвестицій є визначальними факторами при проведенні структурних реформ в економіці. Meта cmammi. В статі розглянути принципи сучасного інвестиційного менеджменту в діяльності місцевих органів державної влади з урахуванням позитивних і негативних явищ, які впливають на процес залучення інвестицій в регіон. Об 'єкт дослідження - інвестиційні процеси на рівні місцевих органів державної влади. Методи, використані в дослідженні: Використовуючи системний підхід були вивчені інвестиційні процеси на державному та регіональному рівні. На основі системного підходу здійснено теоретико-методологічне узагальнення принципів державного регулювання інвестиційного процесу. Економічними і статистичними методами проведено оцінку динаміки інвестиційного процесу. Використання методу колективних оцінок дав змогу виявити інвестиційний рейтинг держави й окремих регіонів України. Робота виконана 3 використанням загальнонаукових та спеціальних методів дослідження економічних явищ та процесів: аналізу і синтезу, логічного узагальнення, аналітично-графічної формалізації та математичних методів. Гіпотеза дослідження складається в можливості забезпечення збалансованої та стійкої системи інвестування регіонів України. Виклад основного матеріалу. Досліджуючи систему державного регулювання інвестиційного процесу в регіоні в роботі означені загальні смислові трактування поняття і важливості механізму системи управління. При цьому були виділені два підходи до трактування поняття механізму державного регулювання регіональним інвестиційним процесом - структурно-організаційний і структурно-функціональний. Система державного регулювання інвестиційного процесу в регіоні притаманні всі ознаки, характерні для складної соціально-економічної системи управління. При цьому базові принципи створення і функціонування будь-яких складних соціально-економічних систем регулювання при використанні їх в системі державного управління інвестиційним процесом в регіоні наповнюються специфічним функціональним змістом, реалізованим через функції, методи і інструменти даної системи. Оригінальність та практична значимість дослідження. На підставі проведеного аналізу встановлено функціональне наповнення базових принципів, методів і інструментів в системі державного регулювання інвестиційного процесу на регіональному рівні. Визначена сутність найважливішого поняття та інструментальної складової системи регулювання - механізму державного регулювання регіональної інвестиційної системи. Висновки. На основі методології прикладних досліджень були визначені стратегічні цілі регіональної інвестиційної політики і пов'язані з нею найголовніше завдання державного регулювання інвестиційного процесу. Інвестиції в регіоні фактично виконують роль найважливішого блоку в розглянутій структурно-функціональної моделі організації інвестиційного процесу, а саме блоку стратегічного управління. Встановлено, що в процесі реалізації конкретного інвестиційного проекту його економічні показники «виходять» на критерії і показники якості державного регулювання соціально-економічним розвитком регіону, беруть участь в їх формуванні. При цьому інтереси окремого інвестора і державної системи управління інвестиціями в регіоні не в усьому збігаються. Цей факт додатково робить процеси стимулювання інвесторів досить складними.
\end{abstract}

Ключові слова:

інвестиції, розвиток, громада, регіон, влада, управління, конкурентоспроможність.

${ }_{1}^{1}$ Розмислов Олександр Миколайович, канд. екон. наук, доцент кафедри «Облік і оподаткування», Східноукраїнський національний університет імені Володимира Даля, м. Сєвєродонецьк, Україна.

Rozmyslov Alexander, Ph.D in Economics, Associate Professor of Accounting and Taxation Department of Volodymyr Dahl East Ukrainian National University, Severodonetsk, Ukraine.

ORCID ID: 0000-0003-1307-9662

e-mail: alexmegalo1971@gmail.com

${ }^{2}$ Серєбряк Ксенія Ігорівна, д-р екон. наук, доцент кафедри «Економіка і підприємництво», Східноукраїнський національний університет імені Володимира Даля, м. Сєвєродонецьк, Україна.

Sieriebriak Kseniia, Doctor of Economic Science, Associate Professor of Economics and Entrepreneurship Department of Volodymyr Dahl East Ukrainian National University, Severodonetsk, Ukraine.

ORCID ID: 0000-0002-7025-2390

e-mail: Serebriakki@ukr.net 


\section{PARADIGM OF EFFECTIVE FUNCTION OF INVESTMENT PROCESS FOR ECONOMICALLY SOCIAL REGION DEVELOPMENT}

Formulation of the problem. Activation of investment action and main volume increase of investment are prominent factors for carrying out structural reforms at economy. The purpose of the research. At article was shown principles of modern investment management at action of local government included positive and negative phenomena, which are influenced by process of engagement investment to region. The object of research is investment processes at the level of local authorities. The methods of the research: using a systematic approach were studied investment processes at the state and regional levels. Based on systematic approach was carried out a theoretical and methodological generalization of the principles of state regulation of the investment process. Economic and statistical methods were evaluated the dynamics of the investment process. The using of the collective valuation method are enabled us to identify the investment rating of the state and individual regions of Ukraine. The work is performed using general scientific and special methods of research of economic phenomena and processes: analysis and synthesis, logical generalization, analytical and graphical formalization, grouping, comparison of statistical data and mathematical methods. The hypothesis of the research consists in the possibility of providing a balanced and stable system of investing in the regions of Ukraine. The statement of basic materials. Investigating the system of state regulation of the investment process in the region are indicated at work for general semantic interpretations of the concept and importance of the mechanism system's control. In this case, two approaches to the interpretation of the notion of state's mechanism regulation of the regional investment process - structural and organizational and structural-functional. It was established that system of state regulation of the investment process in the region also has all features, which are characteristic of a complex socioeconomic management system - the complexity of the mathematical description, stochasticity and non-stationary experiments. At the same time, the basic principles of the creation and operation of any complex socio-economic regulatory systems when using them in the system of public administration of the investment process in the region are filled with a specific functional content implemented through the functions, methods and tools of the investment system. The originality and practical significance of the research. Based on the analysis, the functional filling of the basic principles, methods and tools in the system of state regulations require are established of the investment process at the regional level. The essence of the most important concept and instrumental component of the system of regulation - is determined mechanism of state regulation of the regional investment system. Conclusions and perspectives of further research. Based on applied research methodology, the strategic objectives of regional investment policy and the main task of state regulation were determined of the related investment process. It is established that investments in the region actually fulfill the role of the most important block in the considered structural and functional model of the organization of the investment process, namely, the strategic management unit. It is established that in the process of realization of a concrete investment project, its economic indicators "go out" on the criteria and indicators of the quality of state regulation of the socioeconomic development of the region to take part in their formation. At the same time, the interests of the individual investor and the state investment management system in the region do not coincide in all. This fact, in addition, makes the processes of stimulating investors and managing investment processes at the regional level rather complicated.

Key words:

investment, development, community, region, power, management, competitiveness.

\section{ПАРАДИГМА ЭФФЕКТИВНОГО ФУНКЦИОНИРОВАНИЯ ИНВЕСТИЦИОННОГО ПРОЦЕССА СОЦИАЛЬНО ЭКОНОМИЧЕСКОГО РАЗВИТИЯ РЕГИОНА}

Постановка проблемьl. Активизация инвестиционной деятельности и значительное наращивание объемов инве-стыке являются определяющими факторами при проведении структурных реформ в экономике. Цель статьи. В статье рассмотрены принципы современного инвестиционного менеджмента в деятельности местных органов государственной власти с учетом положительных и отрицательных явлений, которые влияют на процесс привлечения инвес-тиций в регион. Объект исследования - инвестиционные процессы на уровне местных органов государственной власти. Meтоды, использованные в исследовании: используя системный подход были изучены инвестиционные процессы на государственном и региональном уровне. На основе системного подхода осуществлено теоретико-методологическое обобщение принципов государственного регулирования инвестиционного процесса. Экономическими и статистическими методами проведена оценка динамики инвестиционного процесса. Использование метода коллективных оценок позволило выявить инвестиционный рейтинг государства и отдельных регионов Украины. Работа выполнена с использованием общенаучных и специальных методов исследования экономических явлений и процессов: анализа и синтеза, логического обобщения, аналитически-графической формализации и математических методов. Гипотеза исследования состоит в возможности обеспечения сбалансированной и устойчивой системы инвестирования регионов Украины. Изложение основного материала. Исследуя систему государственного регулирования инвестиционного процесса в регионе в работе обозначены общие смысловые тракта ния понятия и важности механизма системы управления. При этом были выделены два подхода к трактовке понятия механизма государственного регули- 
рования региональным инвестиционным процессом - структурно-организационный и структурнофункциональный. Система государственного регулирования инвестиции процесса в регионе присущи все признаки, характерные для сложной социально-экономической системы управления. При этом базовые принципы создания и функционирования любых сложных социал-льно-экономических систем регулирования при использовании их в системе государственного управления инвестиционных процессом в регионе наполняются специфическим функциональным содержанием, реализуемым через функции, методы и инструменты данной системы. Оригинальность и практическая значимость исследования. На основании проведенного анализа установлено функциональное наполнение базовых принципов, методов и инструментов в системе государственного регулирования инвестиционного процесса на региональном уровне. Определена сущность важнейшего понятия и инструментальной составляющей системы регулирования - механизма государственного регулирования региональной инвестиционной системы. Bblвoдbl. На основе методологии прикладных исследований были определены стратегические цели региональной инвестиционной политики и связанные с ней главная задача государственного регулирования инвестиционного процесса. Инвестиции в регионе фактически выполняют роль важнейшего блока в рассматриваемой структурно-функциональной модели организации инвестиционного процесса, а именно блока стратегического управления. Установлено, что в процессе реализации конкретного инвестиционного проекта его экономические показатели «выходят» на критерии и показатели качества государственного регулирования социально-экономическим развитием региона, участвуют в их формировании. При этом интересы отдельного инвестора и государственной системы управления инвестициями в регионе не во всем совпадают. Этот факт дополнительно делает процессы стимулирования инвесторов достаточно сложными.

Ключевые слова:

инвестиции, развитие, общество, регион, власть, управление, конкурентоспособность.

Постановка проблеми. Каталізатором розвитку економіки будь-якої держави $\epsilon$ інвестиції. Інвестиційний процес задає вектор стратегічного розвитку i формує базис для успішного економічного і соціального розвитку країни та іiї регіонів. Активізація інвестиційної діяльності та значне нарощування обсягів інвестицій $є$ визначальними факторами при проведенні структурних реформ в економіці, реалізації соціально-орієнтованої інноваційно-інвестиційної моделі розвитку в Україні. Отже, рішення поточних і довгострокових завдань соціально-економічних реформ вимагає як зваженої, всебічно обгрунтованої інвестиційної політики, так і формування дієвих механізмів державного регулювання інвестиціями з урахуванням особливостей поточного стану господарського розвитку регіонів.

Аналіз останніх досліджень і публікацій. Вагомий внесок у розробку концептуальних основ державного регулювання процесів соціально-економічного розвитку регіонів внесли С. Біла, В. Бодров, З. Варналій, В. Воротін, В. Геєць, А. Градов, В. Гриньова, Л. Дідковська, А. Єпіфанов, Л. Зайцева, А. Мерзляк, М. Миколайчук, І. Михасюк, Н. Ніжник, Н. Чумаченко.

Разом 3 тим слід зазначити, що дослідження функціонування інвестиційного процесу в регіонах поки що проводилося головним чином за окремими факторами впливу. Крім того, залишаються ще не дослідженими належним чином такі питання, як положення щодо участі місцевих органів влади у формуванні інформаційної бази даних про потреби території в інвестиціях з урахуванням реального ресурсного потенціалу.

3 урахуванням поставлених завдань метою статті $\epsilon$ визначення принципів сучасного інвестиційного менеджменту в діяльності місцевих органів державної влади 3 урахуванням позитивних і негативних явищ, які впливають на процес залучення інвестицій в регіон.

Виклад основного матеріалу дослідження. Для України сьогодні надзвичайно актуальною $є$ трансформація державної політики в області інвестицій, докорінна зміна функцій держави в сфері управління інвестиційною діяльністю, а саме, перехід від практикувався раніше розподілу державних капіталовкладень до виконання ролі надійного партнера недержавних вітчизняних і зарубіжних інвесторів при вирішенні найважливіших завдань соціально-економічного розвитку країни.

Країні потрібен принципово новий підхід до формування та реалізації інвестиційноструктурної стратегії розвитку регіонів з використанням можливостей регіонального саморозвитку і регульованих ринкових відносин, що сприятиме гармонійному поєднанню загальнонаціональних та регіональних інтересів. Необхідно йти від існуючої ще практики «експропріації» дохідних коштів у регіонів - донорів 3 подальшим «виділенням» регіону інвестиційних коштів 3 держбюджету.

Організаційно-економічний механізм ре- 
гіонального державного регулювання інвестиційного процесу повинен складатися при взаємодоповнюючому впливу на інвестиційні процеси ринкової кон'юнктури і державного регулювання [1, с. 123].

У теорії державного управління поняття раціональності управлінської діяльності розроблено Г. Саймонтом. На його думку, раціональність рішень пов'язана 3 вибором альтернативних варіантів, оптимальних 3 боку систем цінностей, за якими можна оцінити їх наслідки. Рішення можна назвати «свідомо» раціональним в тій мірі, в якій узгодження способів і цілей є свідомим процесом [2, с. 78$]$.

У зв'язку з цим набуває особливої актуальності проблема розробки методології та методики науково - обгрунтованого формулювання цілей, оцінних критеріїв ефективності і механізмів інвестиційного процесу на рівнях підприємство - регіон - країна.

Інвестиційний процес в регіоні об'єднує наступних суб'єктів: юридичних осібінвесторів (підприємства, організації, інвестиційні банки, інвестиційні компанії, фонди); фізичних осіб (вкладників); органи державного управління, які регулюють функціонування суб'єктів інвестиційної діяльності.

Державне регулювання інвестиційного процесу слід розглядати як систему регулювання, що складається 3 двох підсистем (ланок)
- регулюючої підсистеми (суб'єкт регулювання) і регульованої підсистеми (об'єкт регулювання). Зв'язок суб'єкта регулювання 3 об'єктом регулювання здійснюється за допомогою передачі інформації. Державне регулювання інвестиційного процесу - це процес вироблення і здійснення регулюючого впливу суб'єкта регулювання на об'єкт регулювання.

Суб'єкт регулювання являє собою групу фахівців або орган державного управління в сфері інвестицій, які здійснюють управлінський вплив на об'єкт регулювання для забезпечення стійкого його функціонування і цілеспрямованого впливу.

Об'єктом регулювання $є$ все те, на що спрямовано управлінський вплив суб'єкта регулювання (інвестиції та економічні відносини між учасниками ринку інвестицій) для досягнення цілей і завдань інвестиційної системи.

Організаційно-економічний механізм регіонального державного регулювання інвестиційного процесу повинен складатися 3 урахуванням впливу на інвестиційні процеси ринкової кон'юнктури і державного регулювання.

Інвестиційну систему в регіоні слід розглядати як структурну частину (підсистему) системи більш високого рівня - системи управління і регулювання соціально-економічного розвитку регіону, і функціонуючу з нею на загальних методичних принципах (рис. 1).

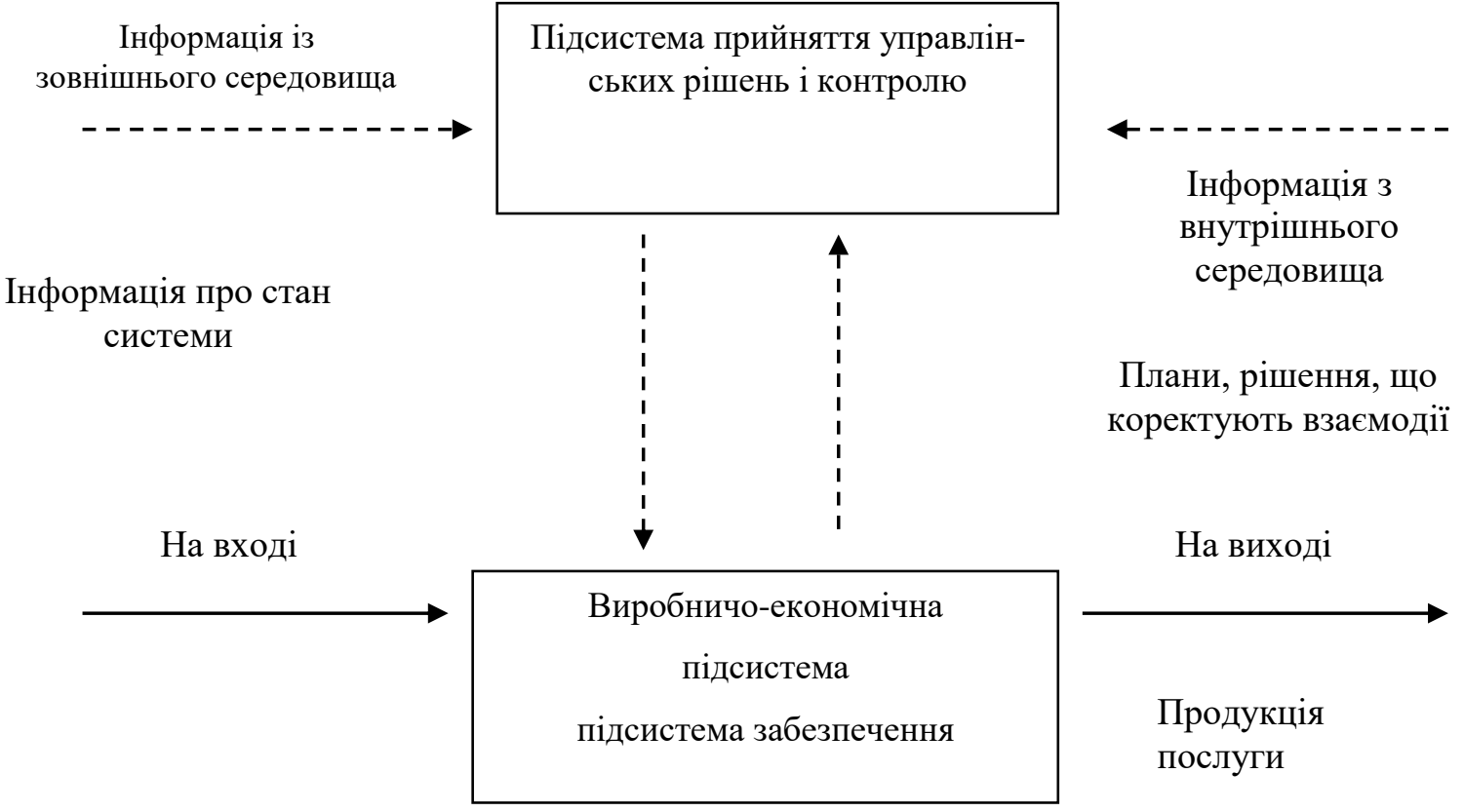

Рис. 1. Принципова схема функціонування системи державного регулювання соціально-економічного розвитку регіону Джерело: розроблено авторами

Для інтегральної оцінки напрямків регулюючого впливу на соціально-економічний розвиток регіону введемо поняття конкурентоспроможність регіону. 
Конкурентоспроможність регіону відрізняється від звичайних економічних показників тим, що завжди включає «свідомо керований» довгостроковий аспект розвитку і оцінює, як регіон формує своє економічної майбутнє.

Таким чином, конкурентоспроможність регіону виступає визначальною цільовою функцією соціально-економічного розвитку регіонy.

За великим рахунком, це здатність регіону досягти і підтримувати високі темпи економічного зростання. В кінцевому ж рахунку, висока конкурентоспроможність регіону призведе до високого рівня якості життя населення.

Конкурентоспроможні регіони є основою конкурентоспроможності країни. Можна стверджувати, що стратегія конкурентоспроможних регіонів може виступати в якості провідної ідеї сучасної державної регіональної політики.

Важливо підкреслити також, що страте-

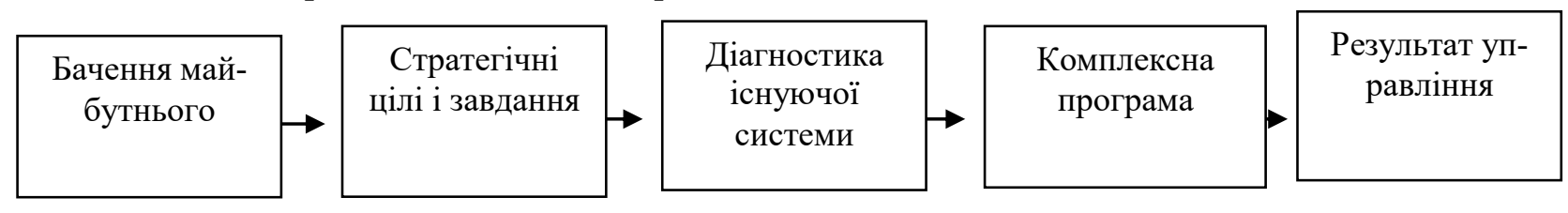

Рис. 2. Загальна схема методології стратегічного управління Джерело: розроблено авторами

Важливим вихідним моментом стратегічного управління обов'язково виступає чітке бачення майбутнього. Можна тому стверджувати, що важливіше не те місце, де ми зараз знаходимося, а той напрямок, куди ми рухаємося. Ситуацію, коли суб'єкт управління здійснює управлінський вплив в умовах відсутності чіткого бачення (розуміння) моделі майбутнього висловлює наступна аксіома сучасного стратегічного менеджменту: «Коли не знаєш куди пливеш, ніякої вітер не буде попутним».

Аналітичний інструментарій системи державного регулювання інвестиційного процесу в регіоні пропонуємо складається з п'яти елементів: принципи, функції, механізми, інструменти і результат функціонування. Пропонована структура інструментарію системи державного регулювання інвестиційного процесу на регіональному рівні представлена на рис. 3.

Слід зазначити, що системі державного регулювання інвестиційного процесу в регіоні притаманні всі ознаки, характерні для складної соціально-економічної системи управління складність математичного опису, стохастичность та нестаціонарність.

При цьому базові принципи створення $\mathrm{i}$ функціонування будь-яких складних соціально- гічні економіко - управлінські завдання виведення окремих регіонів на рівень високої конкурентоспроможності за своєю суттю об'єднує конкурентоспроможності всієї країни.

Конкурентоспроможність регіону формується в значній мірі на основі системи державного регулювання інвестиційного процесу.

Сучасну систему державного регулювання інвестиційного процесу в регіоні, на нашу думку, слід створювати на фундаменті дуже плідною концепції стратегічного управління.

Стратегічне управління - це спосіб втілення бачення майбутнього в реальність, що $\epsilon$ повною протилежністю «інтуїтивного просування».

У спрощеному формалізованому вигляді методологію стратегічного управління можна представити таким чином (рис. 2).$$
\begin{aligned}
& 0 \\
& 7 \\
& 0 \\
& 1 \\
& 1 \\
& 0 \\
& 2
\end{aligned}
$$

економічних систем регулювання при використанні їх в системі державного управління інвестиційним процесом в регіоні наповнюються специфічним функціональним змістом, реалізованим через функції, методи і інструменти даної системи (табл. 1).

Слід зазначити, що у вітчизняній науковій літературі поки немає єдиного підходу до тлумачення поняття механізму державного управління і його складових, проте важливість цієї категорії ніхто не ставить під сумнів. Досліджуючи систему державного регулювання інвестиційного процесу в регіоні, ми дотримуємося загальних смислових трактувань поняття і важливості механізму системи управління. При цьому можливо виділити два підходи до трактування поняття механізму державного регулювання регіональним інвестиційним процесом - структурно-організаційний і структурнофункціональний [2, с. 125].

Для реалізації системи державного регулювання інвестиційного процесу в регіоні пропонуємо наступну структурно-функціональну модель організаційного механізму державного регулювання інвестиційного процесу в регіоні. 


\begin{tabular}{|c|c|}
\hline \multirow{2}{*}{ Принципи } & $\begin{array}{l}\text { 1. Відповідність регіональної інвестиційної політики стратегії економічного і } \\
\text { соціального розвитку регіону } \\
\text { 2. Стимулювання розвитку наукомістких виробництв, випуску конкурентоздат- } \\
\text { них товарів і послуг. }\end{array}$ \\
\hline & $\begin{array}{l}\text { 3. Стимулювання створення нових робочих місць в регіоні } \\
\text { 4. Орієнтація на реалізацію ресурсозберігаючих і екологічних програм } \\
\text { 5. Орієнтація на формування привабливого інвестиційного іміджу }\end{array}$ \\
\hline
\end{tabular}

\begin{tabular}{|c|c|c|}
\hline Функції & $\begin{array}{l}\text { 1. Цільова } \\
\text { 3. Нормативна (регламентує) } \\
\text { 5. Контрольна }\end{array}$ & $\begin{array}{l}\text { 2. Стимулююча } \\
\text { 4. Регулююча }\end{array}$ \\
\hline \multirow[b]{3}{*}{ Методи } & \multirow{3}{*}{$\begin{array}{l}\text { 1. Нормативно-правовий } \\
\text { 3. Економічний }\end{array}$} & \multirow{3}{*}{$\begin{array}{l}\text { 2. Організаційний } \\
\text { 4. Соціальний }\end{array}$} \\
\hline & & \\
\hline & & \\
\hline$t$ & \multirow{2}{*}{\multicolumn{2}{|c|}{$\begin{array}{l}\text { 1. Стратегічне прогнозування, дослідження ринку інвестицій } \\
\text { 2. Забезпечення відповідності фінансових потреб регіону і можливостей інвес- } \\
\text { торів задовольнити їх } \\
\text { 3. Пошук потенційних інвесторів, залучення інвесторів, відбір проектів } \\
\text { 4. Координація процесом інвестування } \\
\text { 5. Контроль над процесом інвестування }\end{array}$}} \\
\hline Інструменти & & \\
\hline$\downarrow$ & & \\
\hline $\begin{array}{l}\text { Результат } \\
\text { функціону- } \\
\text { вання }\end{array}$ & \multicolumn{2}{|c|}{$\begin{array}{l}\text { 1. Підвищення ефективності державного регулювання економіки } \\
\text { 2. Реалізація стратегії розвитку економічної та соціальної сфер регіону } \\
\text { 3. Досягнення ефектів - (бюджетного, регіонального комерційного) від реалі- } \\
\text { зації інвестиційних проектів } \\
\text { 4. Створення сучасної системи державного регулювання інвестиційного про- } \\
\text { цесу в регіоні та підвищення рівня якості ії керованості }\end{array}$} \\
\hline
\end{tabular}

Рис. 3. Аналітичний інструментарій системи державного регулювання інвестиційного процесу в регіоні Джерело: розроблено авторами

Т а б ли ц я 1

Функціональне наповнення системи державного регулювання інвестиційного процесу в регіоні

\begin{tabular}{|l|l|l|}
\hline $\begin{array}{c}\text { № } \\
\text { п/п }\end{array}$ & \multicolumn{1}{|c|}{ Базові принципи системи управління } & $\begin{array}{l}\text { Функціональне наповнення в системі державного } \\
\text { регулювання інвестиційного процесу }\end{array}$ \\
\hline 1 & Об'єктивність, структурованість & $\begin{array}{l}\text { Програмно-цільовий підхід, який реалізуєтья в } \\
\text { програмах фінансової, технологічного, інформа- } \\
\text { ційного, консультаційного, кадрового забезпечен- } \\
\text { ня інвестиційних проектів }\end{array}$ \\
\hline 2. & $\begin{array}{l}\text { Системність, комплексність, соціальна } \\
\text { вмотивованість, довготривалість і стабі- } \\
\text { льність регулювання і підтримки }\end{array}$ & $\begin{array}{l}\text { Знання кінцевої мети, узгодження стратегічних і } \\
\text { такичних цілей в депресивних регіонах або в ок- } \\
\text { ремих галузях }\end{array}$ \\
\hline 3. & Ієрархічність, поділ компетенції & $\begin{array}{l}\text { Раціональний розподіл управлінських функцій між } \\
\text { рівнями влади при значній мірі делегування пов- } \\
\text { новажень на регіональний рівень }\end{array}$ \\
\hline 4. & $\begin{array}{l}\text { Адекватність - відповідність діяльності } \\
\text { держави реальної економічної ситуації і } \\
\text { потребам соціально-економічної системи }\end{array}$ & $\begin{array}{l}\text { Мотивація - реалізація дісвого стимулу залучення } \\
\text { інвестицій в пріоритетні напрямки } \\
\text { Реалізація заходів законодавчого, економічного і } \\
\text { організаційного характеру. } \\
\text { Підтримка інвесторів, мінімальне втручання дер- } \\
\text { жави там, де діє тільки ринок }\end{array}$ \\
\hline
\end{tabular}

Джерело: узагальнено авторами на підставі [1] 
Суть моделі полягає в наступному. Державна інвестиційна політика на регіональному рівні - це комплекс управлінських рішень і регулятивних заходів, які приймаються органами державної влади 3 метою встановлення рівноваги між інвестиційним попитом і пропозицією в регіоні. Концептуальна завдання регіональної інвестиційної політики - забезпечення економічного зростання і підвищення рівня життя населення регіону.

Основними стратегічними цілями регіональної інвестиційної політики слід вважати:

1). Забезпечення сприятливого інвестиційного клімату. 2). Регулювання пропорцій інвестиційної діяльності. 3). Забезпечення раціонального використання інвестицій.

Таким чином, стратегічні цілі регіональної інвестиційної політики і пов'язані 3 ним найголовніше завдання державного регулювання інвестиційного процесу в регіоні фактично виконують роль найважливішого целеполагающего блоку в розглянутій структурнофункціональної моделі організації інвестиційного процесу в регіоні - блоку стратегічного управління.

Саме тут відбувається трансформація концепції стратегічного управління $(\mathrm{CV})$ в етап стратегічного планування (СП)

Ключовим фактором управління регіональним інвестиційним процесом $\epsilon$ інвестиційний проект.

Актуальність інвестиційного проекту в цілому - це відповідність його завданням соціально-економічного розвитку країни, регіону, господарюючого суб'єкта. Тому інвестиційний проект відповідно може мати державну, регіональну, галузеву значимість або значимість для господарюючого суб'єкта. Ці оцінки можуть перебувати в різних поєднаннях стосовно оскільки він розглядався інвестиційному проекту.

В процесі реалізації конкретного інвестиційного проекту його економічні показники «виходять» на критерії і показники якості державного регулювання соціально-економічним розвитком регіону, беруть участь в їх формуванні.

При цьому інтереси окремого інвестора i державної системи управління інвестиціями в регіоні не в усьому збігаються. Цей факт додатково робить процеси стимулювання інвесторів і управління інвестиційним процесом на регіональному рівні досить складними $[3,4]$.

Держава в період формування основ ринкової моделі функціонування економіки виконує активну роль регулятора і стимулятора інвестиційного процесу. Регулювання означає застосування активних метолу впливу на інвес- торів за допомогою організаційних, адміністративних заходів і економічних важелів.

Державне регулювання інвестиційного процесу в регіоні реалізується шляхом встановлення державними органами «правил поведінки» у зовнішньому середовищі, в той час як організаційні структури, стратегія і тактика реалізації інвестицій, стиль і методи керівництва в більшій мірі стають справою безпосередньо інвестиційного менеджменту в регіоні, обов'язково адекватного новим ринковим реаліям.

Регіональний інвестиційний менеджмент - інструмент державного регулювання та професійного управління, що включає в себе сукупність науково-обгрунтованих принципів, методів і функцій управління, що розробляються і що застосовуються з метою забезпечення стійкого, надійного, перспективного і ефективного функціонування інвестиційної системи в регіонi

Підкреслимо також, що необхідно і далі розвивати процеси самоорганізації регіонів, домагатися балансу i розумного узгодження адміністративних відносин гілок влади і економічної свободи бізнесу, обмеженою тільки законом, тобто діалектичної єдності процесів управління «зверху» $з$ управлінням «знизу».

Роль держави в регіонах повинна бути орієнтована на створення сприятливих умов для діяльності інвесторів і контроль за дотриманням прийнятих законодавчих та інших норм без того, щоб самому втручатися у безпосередню господарську діяльність, домагаючись гармонізації державної і ринкової інвестиційної політики на регіональному рівні. Класичний підхід до класифікації факторів впливу на інвестиційну привабливість регіону на фактори прямого впливу (внутрішні) та фактори непрямого впливу (зовнішні) відображені у роботі Н.М. Гуляєвої [5].

Європейська Бізнес-Асоціація бачить головні можливості успішного залучення іноземних інвестицій в наше країну на шляху:

1. Відмови від існуючого сьогодні фаворитизму і створення рівних умов для всіх учасників інвестиційного ринку в країні.

2. Створення в Україні законодавчої бази, яка була б якщо не стабільною, але хоча б передбачуваною.

Стратегічна програма вдосконалення державного регулювання інвестиційного процесу та створення сприятливого інвестиційного клімату в Україні, яка послужить надійною базою для раціоналізації регіональної інвестиційної системи, повинна включати на нашу думку, такі ключові напрямки на макрорівні: 
1. Лібералізація підприємницької діяльності. Необхідно змінити недосконалу процедуру банкрутства підприємств, яка прорив триває роками, не даючи можливості залучати кошти інвесторів у відродженні промисловості.

Малий і середній бізнес в Україні формується сьогодні практично стихійно, хоча і виявився затиснутим в рамках надмірного та неефективного регулювання його діяльності з боку держави. Тільки недосконалістю регуляторної політики щодо формування підприємницького клімату в країні можна пояснити той факт, що після 15 років ринкових трансформацій в Україні питома вага малого та середнього бізнесу в ВВП знаходиться на рівні $15-17 \%$, в той час як в європейських країнах цей бізнес давно став основою міцної національної економіки і зазначений показник досяг 60-65\% [8, с. 7].

2. Стабільність правового поля. В першу чергу, така робота повинна бути проведена щодо цивільного, трудового, податкового та комерційного кодексів, законодавства про захист прав у сфері інтелектуальної власності, патентів, політики передачі технологій і прямих іноземних інвестицій. Не менш важливим $\epsilon$ й забезпечення реального дотримання міжнародних договорів та виконання обгрунтованих рішень іноземних арбітражів.

3. Корпоративне та державне управління. Цей напрямок включає комплекс заходів щодо врегулювання корпоративних прав, діяльності державної адміністрації та приватизації державної власності [9, с. 325].

4. Розвиток фінансового сектора. Розвиток фінансового сектору є дуже важливим для поліпшення інвестиційного клімату в країні. і потребує здійснення такого комплексу, як зняття обмежень на відсоткові ставки за банківськими кредитами і позиками, що дозволить поліпшити роботу банківського сектора шляхом вдосконалення контролю за банківською діяльністю. Крім того, необхідно розширити законодавчу ініціативу, щодо підтримки діяльності іноземних банків і інших фінансових установ в Україні [6].

5. Зниження рівня корупції. За оцінкою НБУ, обсяг відмивання злочинних доходів в країні становить близько 1,5\% ВВП. Україна регулярно звинувачують у корумпованості влади і пособництві у відмиванні грошей $[10$, с. 209].

Для вирішення цієї проблеми країні необхідно створити таку систему відносин органів влади та бізнесу, яка мінімізує можливості зловживання державних чиновників, забезпечить обов'язковість у виконанні прийнятих за- конів і постанов, полегшить отримання законних дозволів і ліцензій.

6. Зниження рівню політичного ризику. Політична стабільність та незалежність обраних економічних пріоритетів які регулярно відбуваються в органах влади була і залишається одним 3 найважливіших позитивних чинників при прийнятті інвестиційних рішень.

7. Іміджева політика країни. Залучення зовнішніх інвестицій вимагають від держави немалих зусиль по формуванню привабливого іміджу країни. Необхідно широко висвітлювати готовність уряду вживати дієвих заходів орієнтованих на ринкову економіку, європейські та світові соціально-економічні стандарти [11, с. 105].

8. Формування ринку операторів зовнішніх інвестицій. Сьогодні, серйозну увагу слід приділити підготовці висококласних фахівців і розробці інвестиційних проектів відповідно до вимог сучасного менеджменту.

9. Розробка сучасної науково обгрунтованої системи державного регулювання інвестиційного процесу.

10. Удосконалення принципів формування і технології реалізації загальнодержавних і регіональних інвестиційних програм.

Особливо слід підкреслити, що істотно збільшити приплив інвестицій можна лише за умови розвитку всього комплексу чинників, які формують привабливий інвестиційний клімат. Недооцінка хоча б однісї складової неминуче призведе до дисбалансу і створить напруженість на інвестиційному ринку України.

Висновки та перспективи подальших досліджень. Таким чином, від ефективності системи державного регулювання інвестиційного процесу залежать рівень оновлення виробництва, модернізація і нарощування основних фондів підприємств народного господарства, успіх структурної перебудови економіки, вирішення соціальних і екологічних проблем. Отже, за важливістю продумана i ефективна інвестиційно-інноваційна політика виступаючи серцевиною економічної політики країни, обгрунтовано претендує на роль національної економічної ідеї.

Перераховані вище заходи, безумовно, не вирішують усіх проблем по успішному залученню інвестицій в економіку країни, але їх слід розглядати як найважливіші і невідкладні напрямки в сфері вдосконалення інвестиційного процесу в першу чергу на макрорівні. Ïx peaлізація створить також міцну базу для формування ефективної регіональної інвестиційної політики. 


\section{Література}

1. Сучасний словник іноземних слів. К.: Абв, 2006. - 789 с.

2. Саймонт Герберт А. Адміністративна поведінка: Дослідження процесів прийняття рішень в організаціях, що виконують адміністративні функції: Пер. 3 анг. / Г. Саймонт. - К.: АртЕк, 2011. - 452 с.

3. Інвестиційний клімат в Україні [Електронний ресурс]. - Режим доступу : http://mfa.gov.ua/ua/about-ukraine/economiccoop.

4. Інвестиційний клімат в Україні [Електронний ресурс]. - Режим доступу: https://ukrstat.org/uk/operativ/operativu0115.html.

5. Гуляєва Н. М. Оцінка інвестиційної привабливості економіки: факторна природа формування / Н. М. Гуляєва // Вісник Запорізького національного університету. - 2012. -№ 1(13). - [Електронний ресурс]. - Режим доступу: http://www.nbuv.gov.ua/portal/natural/vznu.pdf

6. Петряев А. В. Факторы инвестиционной привлекательности. Методика оценки инвестиционной привлекательности региона (отрасли, предприятия) / А. В. Петряев [Електронний pecypc]. - Режим доступу: http://scholar.google.com/scholar_host?q=info.

7. Музиченко A. С. Інвестиційна діяльність в Україні. Проблеми регулювання: навч. посіб. / А. С. Музиченко- К.: Кондор, 2011. $406 \mathrm{c}$.

8. Новицька T. А. Формування ефективної інвестиційної політики України з використанням позитивного досвіді інших країн світу / Т. А. Новицька // Інвестиції: практика та досвід. - 2010. - №9. - C. 6-8.

9. Кравчун О. Механізми державного регулювання інвестиційної діяльності в Україні. / О. Кравчун. Теорія та практика державного управління. - 2012. Вип. 3 (38), - С. 323-332.

10. Рубіш I. I. Ефективність інструментів державного регулювання інвестиційної діяльності в перехідних економіках / I. I. Рубіш // Вісник Львівського торговельно-економічного університету. - Львів: Вид-во Львівського торговельно - економічного університету, 2016. Вип. 51. - С. 207-215.

11. Фінансовий механізм забезпечення сталого розвитку соціально - економічних систем : монографія / за ред. Л. І. Антошкіною, С. А. Навроцького. - Бердянськ: Видавець Ткачюк O.B., 2016. -283 c.

\footnotetext{
Стаття надійшла

до редакції : 27.07.2019 p.
}

\section{Reference}

1. Modern dictionary of foreign words. (2006). Kyiv: Abv, 789.

2. Herbert, S. (2011). Administrative Behavior: Investigating Decision Making Processes in Organizations Performing Administrative Functions. Kyev: ArtEk, 452.

3. Investment climate in Ukraine. Retrieved from: http://mfa.gov.ua/en/aboutukraine/economiccooperation/invest-climat.

4. Investment climate in Ukraine. Retrieved from: https://ukrstat.org/en/operative/operativ2018/zd/iv u/ivu_u/ivu0115.html.

5. Gulyayev, N. (2012). Evaluation of investment attractiveness of the economy: a factor nature of formation. Bulletin of the Zaporizhzhya National University, 1(13). Retrieved from: http://www.nbuv.gov.ua/portal.pdf

6. Petryayev, A. Factors of investment attractiveness. Methods of estimating the investment attractiveness of a region (industries, enterprises). Retrieved from: http://scholar.google.com/scholar_host?q=info:_A nsH32I54wJ:scholar.google.com.

7. Muzychenko, A. (2011). Investment activity in Ukraine. Problems of regulation: training. tool. Kyev: Condor, 406.

8. Novitskaya, T. (2010). Formation of effective investment policy of Ukraine with the use of positive experience of other countries of the world. Investments: practice and experience, 9, 6-8.

9. Kravchun, O. (2012). Mechanisms of state regulation of investment activity in Ukraine. Public administration theory and practice, 3 (38), 323-332.

10. Rubish, I. (2016). The effectiveness of instruments of state regulation of investment activity in transition economies. Visnyk of Lviv Trade and Economic University. Lviv: Issue of the Lviv Trade and Economic University, 51, 207-215

11. Antoshkina, L. \& Navrotsky, S. (2016). Financial mechanism for ensuring sustainable development of socio-economic systems. Berdyansk: Publisher Tkachyuk O., 283.

Стаття прийнята
до друку: 27.09.2019 p.

Бібліографічний опис для цитування :

Розмислов О. М. Парадигма ефективного функціонування інвестиційного процесу соціальноекономічного розвитку регіону / О. М. Розмислов, К. І. Сєрєбряк // Часопис економічних реформ. 2019. - № 3 (35). - C. 83-91. 